\title{
MAXIMUM INHIBITORY DILUTION OF MOUTHWASHES CONTAINING CHLORHEXIDINE AND POLYHEXAMETHYLENE BIGUANIDE AGAINST SALIVARY STAPHYLOCOCCUS AUREUS
}

\author{
Andresa Piacezzi NASCIMENTO ${ }^{1}$, Juliane Maria Guerreiro TANOMARU², Fumio MATOBA-JÚNIOR ${ }^{3}$, \\ Evandro WATANABE ${ }^{1}$, Mario TANOMARU-FILHO ${ }^{4}$, Izabel Yoko ITO ${ }^{5}$
}

\begin{abstract}
1- MSc, PhD Student in Microbiology, School of Pharmaceutical Sciences of Ribeirão Preto, University of São Paulo, USP, Ribeirão Preto, SP, Brazil.

2- DDS, MSc, PhD, Assistant Professor, Department of Restorative Dentistry, Araraquara School of Dentistry, São Paulo State University, Araraquara, SP, Brazil.

3- DDS, MSc Student in Pediatric Dentistry, Ribeirão Preto School of Dentistry, University of São Paulo, USP, Ribeirão Preto, SP, Brazil. 4- DDS, MSc, PhD, Associate Professor, Department of Restorative Dentistry, Araraquara School of Dentistry, São Paulo State University, Araraquara, SP, Brazil.

5- MSc, PhD, Full Professor of Microbiology, School of Pharmaceutical Sciences of Ribeirão Preto, University of São Paulo, USP, Ribeirão Preto, SP, Brazil.
\end{abstract}

Corresponding address: Profa. Dra. Juliane Maria Guerreiro Tanomaru - Rua Humaitá, 1901, apto 182, Centro, Cep.: 14801-385 Araraquara, SP, Brasil - Phone +55-16-3336-4658. Fax. +55-16-3336-4658 - Email: jutanomaru@uol.com.br

Received: February 5, 2007 - Modification: June 4, 2007 - Accepted: June 14, 2007

\begin{abstract}
O

bjective: The aim of the present study was to determine the in vitro maximum inhibitory dilution (MID) of two chlorhexidinebased oral mouthwashes (CHX): Noplak ${ }^{\circledR}$, Periogard ${ }^{\circledR}$, and one polyhexamethylene biguanide-based mouthwash (PHMB): Sanifill Premium ${ }^{\circledR}$ against 28 field Staphylococcus aureus strains using the agar dilution method. Materials and Methods: For each product, decimal dilutions ranging from 1/10 to 1/655,360 were prepared in distilled water and added to Mueller Hinton Agar culture medium. After homogenization, the culture medium was poured onto Petri dishes. Strains were inoculated using a Steers multipoint inoculator and dishes were incubated at $37^{\circ} \mathrm{C}$ for 24 hours. For reading, MID was considered as the maximum dilution of the mouthwash still capable of inhibiting microbial growth. Results: Sanifill Premium ${ }^{\circledast}$ inhibited the growth of all strains at 1/40 dilution and of 1 strain at 1/80 dilution. Noplak ${ }^{\circledR}$ inhibited the growth of 23 strains at 1/640 dilution and of all 28 strains at 1/320 dilution. Periogard ${ }^{\circledR}$ showed inhibited growth of 7 strains at 1/640 dilution and of all 28 strains at 1/320 dilution. Data were submitted to Kruskal-Wallis statistical test, showing significant differences between the mouthwashes evaluated $(p<0.05)$. No significant difference was found between Noplak ${ }^{\circledR}$ and Periogard ${ }^{\circledR}(p>0.05)$. Sanifill Premium ${ }^{\circledR}$ was the least effective $(\mathrm{p}<0.05)$. Conclusion: It was concluded that CHX-based mouthwashes present better antimicrobial activity against $S$. Aureus than the PHMB-based mouthwash.
\end{abstract}

Key words: Bacteria. Anti-infective agents. Chlorhexidine.

\section{INTRODUCTION}

Mouthwashes have been used for centuries ${ }^{19}$ with the objective of reducing the amount of microorganisms in the oral cavity ${ }^{14}$. These chemical agents have been widely employed in the fields of Preventive Dentistry and Periodontics ${ }^{2,10,13}$. Among the microorganisms present in the oral cavity, the reduction in the number of Staphylococcus aureus prior to surgical procedures has been associated with a lower incidence of infective endocarditis and postoperative infections ${ }^{4}$.

Chlorhexidine gluconate (CHX) is a cationic biguanide with broad-spectrum antimicrobial action, whose effectiveness in decreasing the formation of dental biofilm (plaque) and gingivitis has been demonstrated in clinical studies $^{1,5,6,13}$. An important characteristic of chlorhexidine is its substantivity or persistence of action, which consists of the ability of this product to bind to oral tissues and remain active for long periods after application ${ }^{1}$.

The antimicrobial properties of mouthwashes containing $\mathrm{CHX}$ and other antimicrobial agents have been assessed in vivo and in vitro, with excellent results for CHX-based

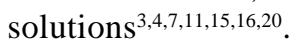

Polyhexamethylene biguanide hydrochloride (PHMB) is 
a polymeric biguanide with broad antimicrobial spectrum against both Gram-positive and Gram-negative bacteria ${ }^{8,9}$. PHMB has been used for several years as an antiseptic agent in Medicine ${ }^{12}$. Welk, et al..$^{23}$ demonstrated in clinical studies that PHMB-based mouthwashes inhibited biofilm formation and reduced contamination in the oral cavity, suggesting that these solutions may be an alternative for prevention of dental biofilm.

The purpose of this study was to determine in vitro the maximum inhibitory dilution (MID) of two mouthwashes containing $0.12 \%$ chlorhexidine gluconate and one mouthwash containing $0.35 \%$ PHMB and to compare their action against 28 Staphylococcus aureus field strains using the agar dilution method.

\section{MATERIALAND METHODS}

The following mouthrinses were evaluated: Periogard ${ }^{\circledR}$ (Colgate-Palmolive, Ind. Brasileira, Osasco, SP, Brazil), Noplak ${ }^{\circledR}$ (Laboratório Daudt Oliveira Ltda., Rio de Janeiro, RJ, Brazil) and Sanifill Premium ${ }^{\circledR}$ (Facilit Odontológica e Perfumaria, Brazil) (Table 1).

Determination of the maximum inhibitory dilution (MID) was performed in duplicate by double serial dilution (from 1 / 10 through $1 / 655.360)$ in test tubes (20x200mm) with $2.0 \mathrm{~mL}$ of sterile distilled water. After dilutions were made, $18.0 \mathrm{~mL}$ of Mueller Hinton Agar culture medium (Difco ${ }^{\circledR}$ ) were added to each tube, and the resulting solutions were poured onto Petri dishes (20x100mm).

The microbial inoculum ( $\left.10^{8} \mathrm{UFC} / \mathrm{mL}\right)$ with turbidity equivalent to a $0.5 \mathrm{McF}$ arland standard was prepared in test tubes (15x125 mm) with saline, using 28 young $S$. aureus field strains previously incubated at $35^{\circ} \mathrm{C}$ for $24 \mathrm{~h}$. S. aureus strains were collected from the oral and nasal cavities of volunteer undergraduate students.

Microorganisms were seeded using a Steers multipoint inoculator ${ }^{21}$. The Steers inoculator consists of two metallic plates: one of these plates has 25 wells into which $200 \mu \mathrm{L}$ of each standardized microbial inoculum were transferred. The other plate has 25 metallic needles that fit into the wells. Using these needles, the inoculi were seeded onto the surface of the culture medium in Petri dishes containing different dilutions of the mouthwashes. Since the Steers inoculator has 25 wells and 28 strains were evaluated, three inoculi (5.0 $\mu \mathrm{L}$ ) were seeded equidistantly from each other, approximately one centimeter from the periphery of each Petri dish, using an automatic pipette.

The dishes were then incubated at $37^{\circ} \mathrm{C}$ for 24 hours, and readings were performed considering the MID as the greatest dilution of mouthwash capable of inhibiting growth of all evaluated strains, following the methodology by Wade and

TABLE 1- Formulation of the antiseptic solutions evaluated

Product Composition

Periogard $^{\circledR}$

Noplak $^{\circledR}$

Sanifill Premium ${ }^{\circledR}$
$0.12 \%$ chlorhexidine gluconate, water, glycerin, ethanol, polysorbate 20 , flavoring agents, sodium saccharin, FD\&C Blue $n^{\circ} 1$

0.12\% chlorhexidine gluconate, water, 3.5\% ethyl alcohol, hydroxyethylcellulose, sodium cyclamate, glycerin, menthol, hydrogenated castor oil, sodium saccharin, sorbitol, $\mathrm{Cl}-19.140$ and 42.090 , flavoring agents, demineralized water

$0.05 \%$ sodium fluoride $(226 \mathrm{ppm})$, sorbitol $70 \%$, sodium benzoate, $0.35 \%$ polyhexamethylene biguanide chlorhydrate, methylsilanol, sodium cocoanphoacetate, disodium monophosphate, disodium phosphate, sodium saccharin, $\mathrm{Cl}-19.140$ and 42.090 , deionized water

TABLE 2- Percentage of $S$ aureus strains inhibited (from a total of 28 strains) by each dilution of the mouthwashes tested

\begin{tabular}{|c|c|c|c|c|c|c|c|c|c|c|c|c|}
\hline \multirow[b]{3}{*}{ Dilution } & \multicolumn{4}{|c|}{ Sanifill Premium } & \multicolumn{4}{|c|}{ Noplak } & \multicolumn{4}{|c|}{ Periogard } \\
\hline & \multicolumn{2}{|c|}{$\begin{array}{l}\text { Inhibited } \\
\text { strains }\end{array}$} & \multicolumn{2}{|c|}{$\begin{array}{l}\text { Cumulative } \\
\text { data }\end{array}$} & \multicolumn{2}{|c|}{$\begin{array}{l}\text { Inhibited } \\
\text { strains }\end{array}$} & \multicolumn{2}{|c|}{$\begin{array}{l}\text { Cumulative } \\
\text { data }\end{array}$} & \multicolumn{2}{|c|}{$\begin{array}{l}\text { Inhibited } \\
\text { strains }\end{array}$} & \multicolumn{2}{|c|}{$\begin{array}{l}\text { Cumulative } \\
\text { data }\end{array}$} \\
\hline & No. & $\%$ & No. & $\%$ & No. & $\%$ & No. & $\%$ & No. & $\%$ & No & $\%$ \\
\hline $1 / 640$ & 0 & 0.0 & 0 & 0.0 & 23 & 82.1 & 23 & 82.1 & 7 & 25.0 & 7 & 25.0 \\
\hline $1 / 320$ & 0 & 0.0 & 0 & 0.0 & 5 & 17.9 & 28 & 100.0 & 21 & 75.0 & 28 & 100.0 \\
\hline $1 / 160$ & 0 & 0.0 & 0 & 0.0 & & & & & & & & \\
\hline $1 / 80$ & 2 & 7.1 & 2 & 7.1 & & & & & & & & \\
\hline $1 / 40$ & 26 & 92.9 & 28 & 100.0 & & & & & & & & \\
\hline
\end{tabular}




\section{MID - Mouthwashes with Clorhexidine (CHX) or Polyhexamethylene biguanide (PHMB)}
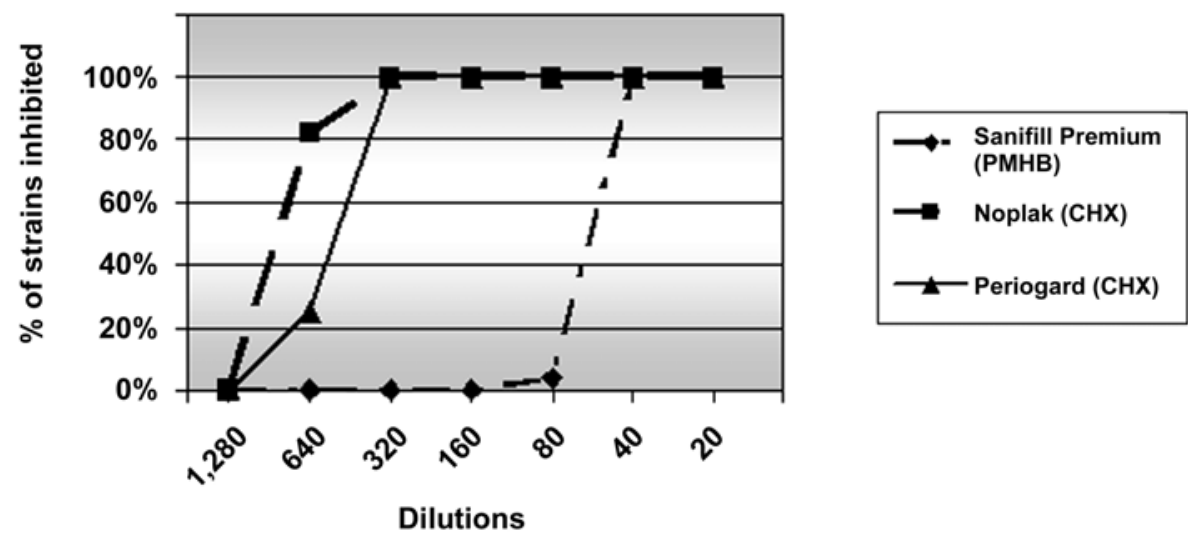

FIGURE 1- Graph depicting MID values obtained for each solution evaluated

$\operatorname{Addy}^{22}$.

\section{Statistical analysis}

Results were expressed as scores determined from minimum to maximum dilution and comparison between all groups was performed using Kruskal-Wallis nonparametric test. When this test showed significant difference between the groups, Dunn's multiple comparison test, which allows two-by-two comparison between groups, was applied. Significance level was set at $5 \%(p<0.05)$.

\section{RESULTS}

The mouthwashes evaluated in this study presented different MIDs (Table 2). No significant difference was found between Noplak ${ }^{\circledR}$ and Periogard ${ }^{\circledR}(p>0.05)$. Sanifill Premium ${ }^{\circledR}$ was the least effective agent $(\mathrm{p}<0.05)$.

\section{DISCUSSION}

Chlorhexidine gluconate mouthwashes are available in the market at concentrations ranging from $0.12 \%$ and $0.2 \%$. Smith, et al. ${ }^{20}$, using the plaque formation index, compared in vivo the dental biofilm-inhibiting properties of mouthwashes containing $0.12 \%$ and $0.2 \%$ chlorhexidine gluconate. Both formulations presented better results than other mouthwashes without CHX. The CHX-based mouthwashes evaluated in this study contain $0.12 \% \mathrm{CHX}$.

Albuquerque Jr, et al. ${ }^{4}$ assessed the MID of a mouthwash containing $0.12 \%$ chlorhexidine gluconate against $25 \mathrm{~S}$. aureus strains, and found that all of them were inhibited up to a 1/80 dilution of the mouthwash. In the present study, the S. aureus strains were inhibited by Periogard ${ }^{\circledR}$ and by Noplak ${ }^{\circledR}$ up to a $1 / 320$ dilution. This difference in the results of both studies may be related to the different sources of the microorganisms. Albuquerque Jr, et al. ${ }^{4}$ used $S$. aureus strains collected from the oral cavity, while in the present study the microorganisms were retrieved from the oral and nasal cavities of the patients.

A study by Herrera, et al. ${ }^{11}$ demonstrated that four mouthwashes containing the same active ingredient $(0.12 \%$ chlorhexidine) but different formulations demonstrated statistically significant differences in their antimicrobial activity, both in vitro and in vivo. For the in vitro antimicrobial activity test, 20 selected bacterial species were evaluated. The in vivo test consisted of salivary bacterial count. The samples were cultured both aerobically and anaerobically. The formulation with alcohol was more active than those without alcohol, except for the formulation with chlorhexidine and cetylpyridinium chloride, which presented better antimicrobial activity. The addition of other active components should be further evaluated because chlorhexidine is highly cationic and may be inactivated by anionic substances ${ }^{11}$.

Our results demonstrated that the CHX-based mouthwashes (Noplak ${ }^{\circledR}$ and Periogard ${ }^{\circledR}$ ) were more effective in inhibiting bacterial growth in comparison to the PHMBbased product (Sanifill Premium ${ }^{\circledR}$ ).

The antimicrobial activity of mouthwashes containing PHMB has been evaluated in several in vivo studies ${ }^{17,18,23}$. In one of these works, Rosin, et al. ${ }^{17}$, using a method that measured bacterial counts on the tooth surface and oral mucosa, demonstrated that a mouthwash with 0.04\% PHMB was more capable of inhibiting biofilm/dental plaque formation, compared to a negative control (placebo); however, the PHMB-based product was not as efficient as a mouthwash containing $0.12 \%$ chlorhexidine. This result is in agreement with our study, in which the PHMB-based mouthwash was not as effective as the CHX-based mouthwashes.

In another in vivo study in which a method to measure bacterial counts on tooth surface and mucosa was used, Rosin, et al. ${ }^{18}$, observed that a mouthwash containing $0.12 \%$ PHMB was more capable of inhibiting biofilm/dental plaque, in comparison to a negative control (placebo), but no statistically significant difference was observed between the 
PHMB-based mouthwash and a product with $0.12 \%$ chlorhexidine. Regarding the ability to reduce the number of intraoral bacteria, the chlorhexidine-based product performed better than the PHMB-based mouthwash. In our study, the evaluated mouthwash contains $0.35 \%$ PHMB, and presented lower MID values than $\mathrm{CHX}$-based mouthwashes containing $0.12 \% \mathrm{CHX}$

An in vivo study ${ }^{23}$ using a method to determine bacterial counts on tooth surface and mucosa demonstrated that a solution containing $0.12 \%$ chlorhexidine was more capable of inhibiting and reducing biofilm/dental plaque than a mouthwash containing 0.2\% PHMB. However, the PHMBbased mouthwash presented similar results to the chlorhexidine solution in reducing the number of bacteria present on the oral mucosa.

The mouthwashes evaluated by Rosin, et al. ${ }^{17,18}$ and Welk, et al. ${ }^{23}$ had a lower concentration of PHMB than the product tested in the present study (Sanifill Premium ${ }^{\circledR}$ ). Despite its higher concentration of PHMB, Sanifill Premium ${ }^{\circledR}$ showed lower MID than the chlorhexidine-based mouthwashes.

\section{CONCLUSIONS}

The mouthwashes containing $0.12 \%$ chlorhexidine (Noplak $^{\circledR}$ and Periogard ${ }^{\circledR}$ ) presented higher MID values than that containing $0.35 \%$ PHMB (Sanifill Premium ${ }^{\circledR}$ ) against salivary $S$. aureus. It was concluded that $\mathrm{CHX}$-based mouthwashes have better antimicrobial activity than the PHMB-based mouthwash.

\section{REFERENCES}

1- Adams D, Addy M. Mouthrinses. Adv Dent Res. 1994;8(2):291301 .

2- Addy M. Chlorhexidine compared with other locally delivered antimicrobials. A short review. J Clin Periodontol. 1986;13:957-64.

3- Addy M, Wright R. Comparison of the in vivo and in vitro antibacterial properties of povidine iodine and chlorhexidine gluconate mouthrinses. J Clin Periodontol. 1978;5:198-205.

4- Albuquerque RF Jr, Head TW, Mian H, Rodrigo A, Müller K, Sanches K, Ito IY. Reduction of salivary S. aureus and mutans group streptococci by a preprocedural chlorhexidine rinse and maximal inhibitory dilutions of chlorhexidine and cetylpyridinium. Quintessence Int. 2004;35:63540 .

5- Bascones A, Morante S, Mateos L, Mata M, Poblet L. Influence of additional active ingredients on the effectiveness of non-alcoholic chlorhexidine mouthwashes: a randomized clinical trial. J Periodontol. 2005;76:1469-75

6- Charles CH, Mostler KM, Bartels LL, Mankodi SM. Comparative antiplaque and antigingivitis effectiveness of a chlorhexidine and an essential oil mouthrinse: 6-month clinical trial. J Clin Periodontol. 2004;31:878-84.

7- Cumming BR, Löe H. Optimal dosage and method of delivering chlorhexidine solutions for the inhibition of dental plaque. J Periodontal Res. 1973;8:57-62.
8- Davies A, Bentley M, Field BS. Comparison of the action of vantocil, cetrimide and chlorhexidine on Escherichia coli and it is sphereoplasts and the protoplasts of gram-positive bacteria. J Appl Bacteriol. 1968;31:448-61.

9- Davies A, Field BS. Action of biguanides, phenols and detergents on Escherichia Coli and it is sphereoplasts. J Appl Bacteriol. 1969;32:23343.

10- Gunsolley JC. A meta-analysis of six-month studies of antiplaque and antigingivitis agents. J Am Dent Assoc. 2006;137:1649-57.

11- Herrera D, Roldán S, Santacruz I, Santos S, Masdevall M, Sanz M. Differences in antimicrobial activity of four commercial $0.12 \%$ chlorhexidine mouthrinse formulations: an in vitro contact test and salivary bacterial counts study. J Clin Periodontol. 2003;30:307-14.

12- Larkin DF, Kilvington S, Dart JK. Treatment of Acanthamoeba keratitis with polyhexamethylene biguanide. Ophthalmology 1992;99:185-91.

13- Lorenz K, Bruhn G, Heumann C, Netuschil L, Brecx M, Hoffmann T. Effect of two new chlorhexidine mouthrinses on the development of dental plaque, gingivitis and discoloration. A randomized, investigator-blind, placebo-controlled, 3-week experimental gingivitis study. J Clin Periodontol. 2006;33:561-7.

14- Menendez A, Li F, Michalek SM, Kirk K, Makhija SK, Childers NK. Comparative analysis of the antibacterial effects of combined mouthrinses on Streptococcus mutans. Oral Microbiol Immunol. 2005;20:31-4.

15- Moran J, Addy M, Newcombe R. A clinical trial to assess the efficacy of sanguinarine-zinc mouthrinse (Veadent) compared with chlorhexidine mouthrinse (Corsodyl). J Clin Periodontol. 1988;15:6126

16- Quirynen M, Avontrootd P, Peeters W, Pauwels M, Coucke W, van Steenberghe D. Effect of different chlorhexidine formulations in mouthrinse on the novo plaque formation. J Clin Periodontol. 2001;28:1127-36.

17- Rosin M, Welk A, Benhardt O, Ruhnau M, Pitten FA, Kocher T, Kramer A. Effect of a polyhexamethylene biguanide mouthrinse on bacterial counts and plaque. J Clin Periodontol. 2001;28:1121-6.

18- Rosin M, Welk A, Kocher T, Majic-Todt A, Kramer A, Pitten FA. The effect of a polyhexamethylene biguanide mouthrinse compared to an essential oil rinse and a chlorhexidine rinse on bacterial counts and 4-day plaque regrowth. J Clin Periodontol. 2002;98:392-9.

19- Sheen S, Addy M. An in vitro evaluation of the availability of cetylpyridinium chloride and chlorhexidine in some commercially available mouthrinse products. Brit Dent J. 2003;194(4):207-10.

20- Smith RG, Moran J, Addy M, Doherty F, Newcombe RG. Comparative staining in vitro and plaque inhibitory properties in vivo of $0.12 \%$ and $0.2 \%$ chlorhexidine mouthrinses. J Clin Periodontol. 1995;22:613-7.

21- Steers E, Foltz EL, Graves BS, Suriano HJ. Comparison of bacterial susceptibility to antibiotics as determined by the plate dilution method and by the disc method. Antibio Annu. 1959-1960;7:604-13.

22- Wade WG, Addy M. Antibacterial activity of some triclosancontaining toothpastes and their ingredients. J Periodontol. 1992;63:280-2.

23- Welk A, Splieth CH, Schmidt-Martens G, Schwahn Ch, Kocher T, Kramer A, Rosin M. The effect of a polyhexamethylene biguanide mouthrinse compared with a triclosan rinse and a chlorhexidine rinse on bacterial counts and 4-day plaque re-growth. J Clin Periodontol. 2005;32:499-505. 